\title{
Cross-infection with Serratia marcescens
}

\author{
GEOFFREY TAYLOR AND P. M. KEANE \\ From the Department of Clinical Pathology, the Royal Infirmary, Manchester
}

SYNOPSIS Cross-infection in a urological unit due to Serratia marcescens is reported. The bacteriology of the organism and its mode of spread are described. It is suggested that Serratia marcescens may be a more virulent organism than is generally believed, especially in situations in which there is an excess of mucus.

The normal habitat of Serratia marcescens (Chromobacterium prodigiosum) is in soil and water. It is usually considered not to be pathogenic to man, but on a number of occasions has been isolated from situations which suggest that it can sometimes behave as a human pathogen. Thus Woodward and Clarke (1913) described its isolation from a patient with bronchiectasis who produced red sputum, and Aronson and Alderman (1943) reported meningitis due to this organism following repeated lumbar puncture. There is good evidence that it can cause subacute bacterial endocarditis (Hawe and Hughes, 1954) and empyema (Papapanagiotou and Aligizakis, 1959). Fatal Serr. marcescens septicaemia has followed superficial infection of an extensive burn (Graber, Tumbusch, Rudnicki, and Vogel, 1960), and mild acute illness has followed human exposure to Serr. marcescens aerosols (Paine, 1946). Urinary tract infections caused by a member of the chromobacterium group, probably Serr. marcescens, were reported by Wheat, Zuckerman, and Rantz (1951). They described 11 cases following genito-urinary manipulation; two developed bacteraemia, one subsequently died of serratia bacterial endocarditis.

None of the published reports give accounts of cross infection with this organism. The seven cases recorded here show that cross infection may occur, adding further evidence that Serr. marcescens is a potential human pathogen.

\section{CASE REPORTS}

CASE 1 A man aged 40 years had been known to have diabetes mellitus for the past 15 years. He was reasonably well until he was scratched by a cat in November 1960 and was given an injection of anti-tetanus serum. He developed severe swelling of the tissues surrounding the scratch and became pyrexial, had rigors, and vomited.

Received for publication 23 October 1961
This pyrexial illness persisted intermittently for several weeks and he was admitted to the local hospital. Whatever the significance of the cat scratch, the symptoms were thought to be due to a urinary infection. He was treated with antibiotics, but relapsed when treatment was withdrawn. He was transferred to the Manchester Royal Infirmary.

Investigation revealed a tight stricture of the penile urethra. The urine was found to contain large numbers of pus cells, and culture yielded a heavy pure growth of Serr. marcescens. Blood cultures on three occasions were sterile. The Wassermann reaction, Price's precipitation reaction, and the gonococcal complement-fixation test were all negative, leaving the aetiology of the stricture in doubt.

He was treated by two-stage urethroplasty with closed bladder drainage from a suprapubic cystotomy wound. Serr. marcescens was isolated from his urine on seven occasions during a period of two months. The infection failed to respond to treatment either with chloramphenicol or with methenamine mandelate.

CASE 2 A man aged 80 years was admitted with acute retention of urine. Culture of the urine at this time was sterile. Investigation showed the patient to be suffering from carcinoma of the prostate, and he was treated by trans-urethral prostatectomy with postoperative closed bladder drainage. Urine examined six days after operation showed large numbers of pus cells, and cultures yielded a moderate growth of Serr. marcescens together with Streptococcus faecalis.

CASE 3 A man aged 64 years was admitted for investigation of haematuria. He was found to have a carcinoma of the bladder which was partially removed at cystoscopy. At this time his urine contained only occasional pus cells and was sterile. Post-operative closed bladder drainage was instituted, and urine examined six days later contained large numbers of pus cells and yielded a moderate mixed growth of Serr. marcescens and Str. faecalis. Treatment with methenamine mandelate resulted in the disappearance of the Str. faecalis but the Serr. marcescens persisted. It was still present together with large numbers 
of pus cells when he was transferred to another hospital for radiotherapy.

CASE 4 A boy aged 11 years was admitted for investigation of incontinence. He was found to have a diverticulum of the bladder and this was excised. Urine examined at the time of operation was sterile. After operation he was treated by closed bladder drainage. Six days later the urine contained large numbers of pus cells, and yielded a heavy mixed growth of Serr. marcescens and Escherichia coli. A later specimen produced a growth of Serr. marcescens only, although no antibiotic treatment had been given in the meantime.

CASE 5 A man aged 69 was admitted to hospital with acute retention of urine. He was known to have had a urethral stricture for many years, and he was now found to suffer from prostatic hypertrophy in addition. He was treated by dilatation of the urethra and continuous bladder drainage. Later a transurethral prostatectomy was carried out. Following operation a urinary tract infection due to Esch. coli developed. This responded to a course of sulphonamide resulting in a sterile urine. Later the pyuria recurred and urine culture produced a heavy growth of Serr. marcescens together with scanty colonies of a Proteus.

CASE 6 A man aged 73 was admitted complaining of urinary frequency and nocturia. He was found to have prostatic hypertrophy and a suprapubic prostatectomy was carried out. At the time of operation the urine was found to be sterile. Closed bladder drainage was instituted after operation. A severe haematemesis four days after the prostatectomy necessitated a partial gastrectomy. Examination of the urine six days after catheterization revealed moderate numbers of pus cells and a pure growth of Serr. marcescens was obtained on culture.

CASE 7 A man aged 75 was admitted to hospital in congestive heart failure and with benign prostatic enlargement. The congestive failure was treated and he was placed on continuous closed bladder drainage. At this time the urine was found to be sterile. Examination of the urine 12 days after admission showed large numbers of pus cells and culture produced a heavy mixed growth of Serr. marcescens, a coliform, and Str. faecalis. He was treated with chloramphenicol for six days when a specimen of urine still contained numerous pus cells and cultures yielded a heavy pure growth of Serr. marcescens.

\section{BACTERIOLOGY}

The strain of the organism isolated from all seven patients gave identical reactions. It was identified as Serratia marcescens on the following criteria (Breed, Murray, and Smith, 1957). It was a Gram-negative motile bacillus growing equally well at room temperature and at $37^{\circ} \mathrm{C}$. on both nutrient agar and on McConkey agar. When grown at room temperature it produced a bright red, non-diffusible pigment which was only very slightly soluble in water at neutral $p H$ but was readily soluble in ether, chloroform, or alcohol. An alcoholic solution: became orange-yellow with the addition of alkali and bright red at acid $p \mathrm{H}$.

The organism fermented glucose, maltose, mannitol dulcitol, and salicin producing acid but no gas. Lactos became slightly fermented after 10 days' incubation Other reactions were as follows:-Indole negative, M.Rฉ negative, Voges-Proskauer positive growth and positive్ in Koser's citrate, catalase positive, coagulase negative, $\mathrm{H}_{2} \mathrm{~S}$ negative, Möller's $\mathrm{KCN}$ positive. Litmus mill turned acid and clotted and when grown in gelatine it $\vec{\omega}$ produced infundibuliform liquefaction and intense pig ment.

The organism was tested for antibiotic sensitivity by the disc technique. It was resistant to penicillin, streptoer mycin, chloramphenicol, tetracycline, sulphonamide, and nitrofurantoin and sensitive to kanamycin, polymyxin $\vec{\Delta}$ and methenamine mandelate.

\section{MODE OF CROSS-INFECTION}

All the Serr. marcescens urinary tract infections occurre during a period of one month and all the patients were treated in the same urological ward. With the exceptionof the first patient who was admitted already suffering from the infection, all the other patients developed urinary tract infections due to Serr. marcescens within short time of catheterization. Before transfer to the surgica ward Case 1 was investigated in another ward withou? being catheterized. No serratia infections were recognized in this ward. These facts strongly suggest that catheteri zation played an important part in the spread of the organism. It was thought to be unlikely that catheteri $\overrightarrow{\overline{0}}$ zation in the operating theatre was the source of the infection as other patients treated in the same theatre by similar techniques but nursed in a different ward did nơ. develop urinary tract infections due to Serr. marcescens nor did patients on the same urological ward who were treated by means other than closed bladde? drainage.

The possibility of aerial transfer of the organism withio the ward was investigated, and attempts made to isolate it from the air, dust, bed linen, curtains, and pieces $\oint \oint$ ward equipment. All were unsuccessful. The metho used to sterilize the catheters and collecting bottles wa tested and found to be adequate. Thus faulty aseptie technique in the management of the bladder drainagg seemed to be the most likely mode of spread. It was found that in all cases the closed drainage systems were being opened frequently in order to take catheter specivo mens of urine for examination. For part of the time Case 1 had samples of urine examined for sugar at four-hourly intervals because of his diabetes. The war routine was to collect specimens of urine and empty the collecting bottles serially from patient to patient, sq that should an unsatisfactory aseptic technique b8 employed cross-infection was inevitable. Careful attentio to aseptic technique and the restriction of the number 0 P times the closed drainage systems were opened has resulted in no further cases of Serr. marcescens infectiog in the ward.

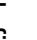




\section{DISCUSSION}

The relative infrequency with which infections due to Serr. marcescens are reported would suggest either that this organism behaves as a very low-grade pathogen, and hence only causes infections in very favourable conditions, or that infections are more common but fail to be recognized. Many of the reported cases of infection due to Serr. marcescens have occurred in association with chronic disease. In these circumstances it would be expected that either local or general resistance to infection would be low. Thus Serr. marcescens infections have complicated established urinary tract disease (Wheat et al., 1951), chronic pulmonary disease (Woodward and Clarke, 1913; Robinson and Woolley, 1957; Gale and Lord, 1957), severe burns (Graber et al., 1960), and debilitation due to recurrent peptic ulcer (Patterson et al., 1952). On the other hand, the occurrence of seven cases of Serr. marcescens infection in one surgical ward at the same time shows that in some circumstances this organism can behave in a much more communicable manner than has been previously recognized. Further, the finding of considerable pyuria, associated in five of the cases with a pure growth of Serr. marcescens, suggests that this organism must be considered to be a human pathogen. It has been found that the mouse virulence of a strain of Serr. marcescens was increased when the organisms were injected together with mucin (Gale and Lord, 1957), and perhaps the excessive mucus secreted around the indwelling catheters of the cases described played a part in increasing the virulence of the organism.

Serratia marcescens does not produce the characteristic pigment if it is grown at $37^{\circ} \mathrm{C}$. Therefore, if media are not incubated at a temperature lower than $37^{\circ} \mathrm{C}$., or non-lactose-fermenters growing on McConkey's medium are not investigated in detail, then strains of Serr. marcescens may be reported as 'atypical coliform organisms'. For this reason Serr. marcescens infections may be more common than is recognized. It should be noted, however, that a survey of the Enterobacteriaceae isolated from infective lesions in the Manchester Royal Infirmary over a period of four months did not reveal any strains of Serr. marcescens other than those described here.

In common with other strains of Serr. marcescens described in the literature the organism responsible for this outbreak proved to be resistant to most of the available antibiotics. Although sensitive by the disc technique to methenamine mandelate, treatment by this substance failed to cure the infection. Chloramphenicol was suggested by Robinson and Woolley (1957) and by Papapanagiotou and Aligizakis (1959) but this antibiotic failed to improve the three patients in this series in whom it was tried. The ideal form of treatment for Serr. marcescens infections is still to be found.

We wish to thank Mr. T. Moore for permission to investigate patients under his care and for his cooperation during this study.

\section{REFERENCES}

Aronson, J. D., and Alderman, S. I. (1943). J. Bact., 46, 261.

Breed, R. S., Murray, E. G. D., and Smith, N. R. (1957). Bergey's Manual of Determinative Bacteriology, 7th ed., p. 361. Williams \& Wilkins, Baltimore.

Gale, D., and Lord, J. D. (1957). J. Amer. med. Ass., 164, 1328.

Graber, C. D., Tumbusch, W. T., Rudnicki, R. P., and Vogel, E. H. Jr. (1960). Surg. Gynec. Obstet., 110, 443.

Hawe, A. J., and Hughes, M. H. (1954). Brit. med. J., 1, 968.

Paine, T. F. (1946). J. infect. Dis., 79, 226.

Papapanagiotou, J., and Aligizakis, C. (1959). J. clin. Path., 12, 170.

Patterson, R. H. Jr., Bannister, G. B., and Knight, J. (1952). A.M.A. Arch. intern. Med., 90, 79.

Robinson, W., and Woolley, P. B. (1957). Lancet, 1, 819.

Wheat, R. P., Zuckerman, Anne, and Rantz, L. A. (1951). A.M.A. Arch intern. Med., 88, 461.

Woodward, H. M. M., and Clarke K. B. (1913). Lancet, 1, 314. 